\title{
Erratum to: Organizational and Social Perspectives on Information Technology
}

\author{
Richard Baskerville ${ }^{1}$, Jan Stage ${ }^{2}$, and Janice I. DeGross ${ }^{3}$ \\ 1 Georgia State University, USA \\ 2 Aalborg University, Denmark \\ 3 University of Minnesota, USA
}

\section{Erratum to:}

\section{R. Baskerville et al. (Eds.)}

\section{Organizational and Social Perspectives}

\section{on Information Technology}

\section{DOI: $10.1007 / 978-0-387-35505-4$}

The book was inadvertently published with an incorrect name of the copyright holder. The name of the copyright holder for this book is: (c) IFIP International Federation for Information Processing. The book has been updated with the changes. 